\title{
Soviet Use of Corruption Purges as a Control Mechanism: The Uzbekistan Case John Staples
}

\begin{abstract}
In a series of purges between 1982 and 1988 , the Soviet government sacked many of the Uzbekistan Communist Party's elite and replaced them with people of unquestionable loyalty to the Kremlin. These purges, which were justified by charges of widespread corruption in the Uzbek Party, have been widely interpreted as indicating a profound change in the policies of the Soviet government, initiated by Yuri Andropov and continued by Mikhail Gorbachev. This essay argues that purges of the type carried out in Uzbekistan were a standard feature of the Kremlin's policy under Brezhnev, and that the first symptom of the Uzbekistan purges manifested themselves well before 1982. The purges should be seen, therefore, as evidence of continuity between the nationalities policies of Brezhnev and his successors, rather than evidence of a changed policy.
\end{abstract}

In June 1984 Egor Ligachev, a secretary of the Communist Party of the Soviet Union (CPSU), flew to Tashkent and addressed a plenum of the Central Committee of the Uzbekistan Communist Party.' There, for the first time, he publicly acknowledged that the widespread changes among government office-holders in Uzbekistan over the preceding eighteen months were a reaction to deep-rooted corruption in the republic. Western observers had long recognized that corruption was widespread in Uzbekistan. But, as understood in the West and arguably in the USSR, corruption had a positive as well as negative function in the Uzbek economy. ${ }^{2}$ The extent of the purges that began to rock the republican Party in 1984 and continued until 1988 was therefore a surprise to many. When those purges were extended beyond the economic sphere to include ideological targets, their objective was not just to increase economic efficiency but to quell nationalist sentiments as well. Commencators have since suggested that the purges, by disrupting Uzbek society, served to destabilize the republic and thereby contributed to the republican nationalism that played such a prominent role in the USSR after 1984. Such an interpretation fits neatly with general perceptions that the attitude of the Soviet leadership changed markedly after the death of Leonid Brezhnev in 1982, but it ignores the fact that the special problems Uzbekistan posed for the Soviet leadership were a topic of debate for over a decade prior to Brezhnev's

Past Imperfect, Vol. 2, 1993, pp. 29.48 
death, and that, arguably, the purges were initiated long before Yuri Andropov became chairman of the Party in 1982. The purges of the 1980 s should therefore be regarded as evidence of the continuity of nationalities policy between the old and new leadership rather than as evidence of change.

The corruption that pervaded Uzbek society in the 1970 s and 1980 s is well documented. Official positions, from government ministries to collective farm directorships, were bought and sold on the open market, and even jobs in meat cutting plants, shoe stores, and lemonade stands could be had only with payment of the requisite bribes. ${ }^{3}$ Within the USSR such corruption was not, of course, unique to Uzbekistan. As Konstantin Simis asserted in 1982, "corruption, even in the highest stratum of the Soviet ruling elite, has become a fact, and not even a rare fact." In Uzbekistan the Soviet system found a happy compliment in the oriental tradition of Baksheesh and clan traditions. The paternalism of Islamic society led to rampant nepotism. ${ }^{5}$ Kinship was a primary qualification for appointment to official positions at all levels of Uzbekistan's government, and the Soviet policy of centralizing authority in the hands of the political elite lent itself particularly well to assimilation with such traditions. $^{6}$

There is little doubt that the Soviet government was aware of the extent of corruption in Uzbekistan long before the purges began. In the 1970s, when Sharif Rashidov, First Secretary of the Central Committee of the Uzbekistan Communist Party became embroiled in a feud with Mankul Kurbanov, Chairman of the Council of Ministers of Uzbekistan, and Yaggar Nasreddinova, Chairman of the Presidium of the Supreme Soviet of Uzbekistan, "the main tactic employed by both sides ... was sending revelatory denunciations to Moscow." This dispute, which resulted in a public trial and imprisonment for Kurbanov, surely provided the central government in Moscow with all the evidence it needed to purge the Uzbek leadership. ${ }^{8}$ Indeed, in view of the ease with which Nancy Lubin, a British political scientist, collected evidence of corruption during her scay in Uzbekistan in 1978-1979, it is difficult to imagine that the Kremlin was not well aware of the same type of evidence, even without denunciations provided by prominent Uzbek officials.'

The explanation for the Soviet government's tolerance of corruption in Uzbekistan was rooted in the essentially colonial economic relationship between Moscow and Uzbekistan. Uzbekistan provided 
for the USSR's domestic cotton requirements as well as producing a significant cash crop for international export. Moscow in turn provided for Uzbek needs which Uzbekistan alone could not satisfy because the local economy was diverted almost exclusively to the production of cotton. Between 1975 and 1985 cotton was the Soviet Union's single largest agricultural export, and Uzbekistan accounted for two-thirds of the USSR's cotton production. ${ }^{10}$ In 1975, Uzbek cotton produced some $\$ 35$ billion on the international market, or 3 percent of total Soviet exports for the year. " Although China's entry into the world market in the late 1970s drove the world price of cotton down and reduced the USSR's share of the world market from 30 to 24 percent, in 1985 cotton remained an important export crop and continued to represent 65 percent of Uzbekistan's gross economic outpur. ${ }^{12}$ Uzbekistan, however, produced only raw cotton, accounting for a mere 6.5 percent of Soviet textile manufacturing. The European republics took the rest of the raw cotton for their textile factories. ${ }^{13}$ Meanwhile, Uzbekistan was constrained to import food, farming machinery, and even textiles. As a result, imports exceeded exports by a factor of two, and even then official estimates suggest that Uzbekistan's per capita consumption of basicgoods such as dairy products, eggs, meat, and fish, was only half the Sovier norm..$^{14}$

Within this system the shadow economy supplied many consumer needs not met by the central government. Unofficial estimates had black-market trade placed at twenty percent of official trade. ${ }^{\text {is Such }}$ a system, operating on a large scale, required that both police and government officials be deeply involved, and evidently such officials "lubricared the whole system." ${ }^{16}$ Of course, in a system where it was assumed that a significant part of each person's daily needs would be acquired on the black-market, it was also necessary to assume that each person would supplement his or her income in order to make illicit purchases. Therefore, the theft of goods from the work place for sale on the black-market also became a tolerated part of the Uzbek economic system. ${ }^{17}$ This situation had a perverse benefit for the Uzbekistan's economy, for the involvement of everyone in society from top to bottom in corruption "helped to make the system work, by stimulating initiative, cementing working relationships, and easing popular dissatisfaction with the state-controlled sector of the economy." 
The purges that put an end to official acceptance of corruption in Uzbekistan are usually associated with Yuri Andropov's rise to power. Brezhnev died on 10 November 1982 and Andropov was named his successor a day later. ${ }^{19}$ As KGB Chairman from 1967 until May 1982 and a Secretary of the Central Committee from May until November 1982, Andropov influenced the Kremlin's policy toward corruption, but only after becoming General Secretary of the Communist Party did he have the opportunity to set that policy. He quickly moved to replace the head of the Ministry of Internal Affairs (MVD), the agency primarily responsible for dealing with corruption, with his own man, Vitaly Fedorchuk. Fedorchuk, who served as head of KGB in the Ukraine from 1970 to June 1982 and then as Andropov's replacement as Chairman of the KGB from June until December 1982, was well known for his hardline approach to dissidence in the Ukraine. ${ }^{20} \mathrm{As}$ an ally of Andropov's, he brought the MVD firmly under Andropov's control and insured that the MVD would cooperate with the KGB in efforts to curb corruption.

Although the details of the investigations have not been released, it appears that such efforts were quickly under way in Uzbekistan. In Seprember 1988 Yurii Churbanov, who had been First Deputy Chief of the MVD in 1983, was brought to trial for accepting bribes from members of the Uzbek MVD in exchange for covering up investigations of Uzbek Party officials in the spring of 1983.21 Churbanov was Brezhnev's son-in-law, so his removal had political overtones that went well beyond the Uzbekistan situation, but eight members of the Uzbek MVD also stood trial with Churbanov. The eight were accused of threarening to kill Uzbek chief investigator Telman Gdlyan in order to put a stop to his investigations. ${ }^{22}$ Spring 1983 also saw the sacking of Uzbek KGB chairman L. M. Melkumov, but he was apparently a victim of the corruption, itself, and not of the purges. Melkumov initiated an investigation into the activities of Abduvakhid Karimov, first secretary of the Bukharin Obkom, who used his connections to have Melkumov fired. Karimov himself was dismissed in 1984, and ultimately arrested, tried, and, in 1987. sentenced to death for his role in Uzbek corruption. ${ }^{23}$ Khaidar Khalikovich Yakh'yaev, Melkumov's successor as KGB head and an obvious appointee of Karimov, stood trial with Churbanov in 1988 on the same charges. ${ }^{24}$

While investigations into corruption in Uzbekistan were under way in the spring of 1983, not until Inamzhon Usmankhodzhaev 
replaced Rashidov as chief of the Uzbekistan Communist Party in November 1983 did the purges begin on a large scale. Rashidov had been First Secretary of the Uzbekistan Communist Party since 1959 and a candidate member of the Soviet Politburo since $1961 .{ }^{25} \mathrm{He}$ died of an apparent heart attack, at the age of 65 , at the end of October 1983 so any attempt to link his "removal" to the purges seems dubious at best. Still, Ann Sheehy suggests that his heart attack may have been brought on by pressure from Moscow, while James Critchlow feels his death may have been suicide. ${ }^{26}$

Regardless of the cause of Rashidov's death, the events that followed Usmankhodzhaev's appointment provide clear and dramatic evidence that a purge was in progress. Usmankhodzhaev began his house cleaning with the head of the KGB, Lieutenant General Kh. Yakh'yaev. ${ }^{27}$ In the following six months, Yakh'yaev was followed by the first secretaries of the Dzhizak, Kashkadarya, and Karakalpak Obkoms. ${ }^{28}$ They were soon joined by the Minister of Finance, the deputy Minister of Health, and the Minister responsible for the cotton-ginning industry. ${ }^{29}$ At the October 1984 plenum of the Central Committee of the Uzbek Communist Party, the first secretary of the Dzhizak City Party Committee, the first secretary of the Namangan Obkom, and the first secretary of the Bukharin Obkom were added to the list. ${ }^{30}$ At the same time, Akhmadzhan Odilov, the general director of the Uzbekistan Agro-Industrial Association, was expelled from the Party and arrested. ${ }^{31}$ Odilov had been a delegate to the twenty-fifth Congress of the CPSU in 1976 and a deputy to the USSR Supreme Soviet in 1974 and 1979, and as recently as 1983 Pravda had printed a "two part article praising his energy and approach." 32 The arrest of such a prominent official was highly unusual. ${ }^{33}$

When the purges first came into the open through Ligachev's speech to the plenum of the Central Committee of the Uzbekistan Communist Party in June 1984, they appeared to be directed primarily at the economic sphere. They extended into the lowest level of Uzbekistan's economy, numbering among their victims farm managers and even shop clerks. ${ }^{34}$ As the purges continued, however, the ideological realm also became a target. The first important ideological figures to be dismissed were the chairman of the Uzbek State Commission for Publishing Houses, Printing Plants, and the Book Trade (January 1984), the first secretary of the Uzbek Writer's Guild (April 1984), and the President of the Uzbek Academy of 
Sciences (September 1984). ${ }^{35}$ A stream of dismissals followed in 1985 and 1986.36

By the time of the Uzbek Party Congress in February 1986, the purges had resulted in an almost complete turnover of party officials. Forty of sixty-five Obkom Secretaries including ten of thirteen First Secrecaries and over two hundred and sixty City and Raion Party Committee Secretaries had been replaced, and fully one-third of the chairmen of the City and Raion Executive Committees faced criminal charges. ${ }^{37}$ Only thirty-four of one hundred and seventyseven members of the Uzbek Central Committee remained unchanged from the previous Congress in $1981 .^{38}$ Seventy-six of the eighty-five candidate members from 1981 were not reelected. By comparison in 1981 two-thirds of the candidate members from 1976 were reelected. ${ }^{39}$ Every Secretary of the Central Commitree was replaced berween 1981 and 1986, some more than once. ${ }^{40}$ The February 1986 Party Congress marked the end of the most severe period of the purges, but they continued at a trickle for two more years. The most nocable victim after 1986 was Usmankhodzhaev, who had initiated the spree when he replaced Rashidov in 1983. On 12 January 1988 he retired "for reasons of health" and was replaced by Rafik Nishanov. ${ }^{41}$ Although Usmankhodzhaev managed to bow out of Uzbek political life in a more honourable manner than many of his associates, likely his failure to rectify Uzbekistan's economic woes, along with the continuing allegations of corruption in the republic, led to his resignation. ${ }^{42}$

The extent of the purges alone makes them an important event, but perhaps as important is the fact that the Kremlin used the purges to fill many republican positions traditionally reserved for titular Uzbeks with Slavs. ${ }^{43}$ Usually the Slav replacement was not a previous resident of Uzbekistan, but a trusted member of the Party brought in from a European republic. While Uzbeks made up seven of eleven members of the Central Committee of the Uzbekistan Communist Party in 1981, by 1986 only six of thirteen were Uzbeks, and, while in 1981 three out of every four candidate members were Uzbeks, in 1986 three out of every five were Slavs. ${ }^{44}$ By 1986 , Slavs also held three of six Party Secretariats, where they had never previously held more than two. ${ }^{45}$ Clearly the Kremlin made a conscious attempt to place people of unquestionable loyalty in places of authority in Uzbekistan. 
Because the purges began under Andropov's tenure and reached their most active phase under Mikhail Gorbachev, they have come to be regarded as a feature of the post-Brezhnev era. Perhaps the most thorough account of the purges is Michael Rywkin's. He feels that the situation that existed during the Brezhnev years was a kind of "gentlemen's agreement" between Moscow and Uzbekistan and that, "in mounting the anti-corruption campaign, Brezhnev's successors reneged on this understanding without any compensating relaxation of the demand for allegiance to Moscow. ${ }^{\text {"46 }}$ Ultimately, Rywkin believes that Moscow's "attempt to retain control of the Muslim republics" through corruption purges and the "parachuting" of Russian cadres into Uzbekistan could only "be even more destabilizing than letting them go their own way. " Paul Goble offers a similar interpretation, suggesting that perestroika was an invication for the nationalities to become politically involved in the USSR, but the purges eliminated the ethnic leaders who might have represented Central Asia within a more decentralized USSR, and thereby deepened the alienation of the Central Asian Republics from Moscow. ${ }^{48}$ Boris Rumer emphasises that it was the policy of importing Russian cadres that was "the canalyst to a nationalistic backlash. " In the case of each of these authors there is agreement that it was Andropov who initiated the changes in policy that brought about the purges and ultimately destabilized the political situation.

This interpretation ignores the fact that in the decade preceding Brezhnev's death, Uzbekistan's Party leaders proved increasingly unable to uphold their end of the "gentlemen's agreement." Their failure to increase or even maintain levels of economic output, their inability to deal with increasing manifestations of Uzbek nationalism, and their failure to deal with Moscow's demographic plans had all come to the attention of Brezhnev and his lieutenants, and there is ample evidence that the corruption purges were a part of the Kremlin's plans well before Andropov had an opportunity to intervene.

The economic failures were perhaps the most damning for the Uzbek government. The Kremlin considered the production of cotton to be Uzbekistan's "internationalist duty," and they judged the Uzbek Party organization "to a large extent by the size of Uzbekistan's cotton harvest." ${ }^{30}$ During the five-year plan that ended in 1980, Uzbekistan's reported cotton production far exceeded plan targets, reaching its peak in 1980 at $6,245,000$ tons, some 500,000 
tons over the target. ${ }^{51}$ This represented an increase of $1,245,000$ tons from the last year of the previous plan in 1975.52 During the purges, however, officials at all levels of the Uzbek cotton industry engaged in gross padding of production figures. ${ }^{53}$ The corruption makes estimating Uzbek cotton production difficult, but Leslie Dienes suggests that the reduction in reported cotton production between 1980 and 1985 - from 6,245,000 to 5,378,000 tons - might not represent a reduction in production at all, but simply an increase in the honesty of the reports. ${ }^{54}$ It should be noted that the $5,378,000$ tons reportedly produced in 1985 is roughly the same amount of cotton as produced in 1974, the best year of the 1971-1975 five-year plan. 55 If the 1974 figure is accurate, admittedly a highly questionable assumption, then Uzbek cotton production experienced a zero growth rate in the following decade. In fact, in 1987 an article in Literaturnaia Gazeta suggested that Uzbek cotton production had experienced no real growth since 1969.56 The central government in Moscow must have realized that the reported production figures were much higher than real production. While there is no hard evidence to prove that Moscow knew about the padding, it is curious that they set plan targets for 1981-1985 at levels below the reported production in $1980 .{ }^{57}$ The Government's actions may indicate a tacit acknowledgement of the padding. Coupled with the lack of growth in production was a disastrous reduction in the quality of Uzbekistan's cotton. Between 1975 and 1982, first and second quality cotton as a share of total production dropped from 70 percent to 46 percent, causing a net reduction in the value of the crop despite (reported) increases in output. ${ }^{38}$

The blame for Uzbek failures in cotton production must be shared by the central government in Moscow, because the pressure to produce cotton at any cost came from the Kremlin. By 1980, "by ignoring proper crop rotations, by making excessive use of harvesters, and by overusing pesticides," the cotton industry had so depleted the soil in Uzbekistan that it simply could no longer sustain the levels of production required. 59 Meanwhile, by extending the acreage under production to "its absoluce outer limits" through the use of excessive irrigation, Uzbekistan had brought less fertile and therefore less productive land under cultivation, and had badly over-strained water supplies in the region. ${ }^{60}$ Having reached the natural limits imposed by the land, Uzbek officials turned to the only option left open to them in meeting Moscow's demands: lying. Still, the fact 
remains that wherever the blame rests, the "gentlemen's agreement" between the Uzbeks and Moscow had outlived its usefulness in economic terms.

While accomplishing economic objectives was the first and paramount objective of the "gentlemen's agreement," controlling ethnic unrest was an important second consideration. Here too Uzbekiscan's leaders experienced increasing problems throughout the 1970s and early 1980s. Perhaps the most dramatic instances of such unrest occurred in 1978 when a new chemical factory in Chirchik and a theatre in Tashkent were blown up, apparently as a protest against Moscow. ${ }^{61}$ There are many more subtle examples that demonstrate growing ethnic turmoil. Placards reading "Russians Go Home" began to appear at public rallies, while native shopkeepers began to refuse to sell to Russian shoppers. ${ }^{62}$ Uzbek newspapers took a growing interest in the Islamic religion, a topic that became increasingly controversial as the situation in Afghanistan developed into war. ${ }^{63}$ Uzbek writers began to produce historical novels focusing on pre-revolutionary times. ${ }^{64}$ One such novel, Immortal Cliff, written in 1981 by Mamadali Mahmudov and published in the important Uzbek literary journal Sharg yulduzi, produced an uproar with its "nationalistic and anti-Russian overtones," and the subject of how such a work came to be published was still debated in $1986 .{ }^{65}$

Here again, the Uzbek government should not bear the total blame, for clearly the deteriomating economic conditions in Uzbekistan acted as a spur to ethnic problems. Over-concentration on cotton production in Uzbekistan resulted in the republic being unable to supply other consumer needs locally, and Moscow was unable or unwilling to satisfy local demands fully. At the same time, excessive irrigation began to have dramatically detrimental effects on the republic's ecology. The water level of the Aral Sea fell by fourteen meters between 1959 and 1989 , leaving behind immense salt flats. ${ }^{66}$ Wind blown salt decreased the fertility of the already damaged soil and infiltrated the food chain to the point where the salt content in the milk of nursing mothers in the Aral region was several times higher than normal. ${ }^{67}$ The sea, which once was a major source of food for the surrounding area, became increasingly salinized and less and less capable of supporting life. ${ }^{68}$ The indigenous peoples, who could not help bur be aware of the deteriorating conditions, began "to hold 'the Russians' responsible for everything." 69 In James Critchlow's words, the "Aral issue ... was made to order as a theme of national- 
ism... As a symbol of environmental abuse, the Aral heightened public outrage over what outsiders had done to the Central Asian homeland. ${ }^{70}$ Regardless of the reasons for increasing ethnic strife, the "gendemen's agreement" was no longer effective in controlling it.

The final failing of the "gentlemen's agreement" was not a failure of the Uzbek leaders to maincain the status quo, but the inability of the existing system to deal with the USSR's larger demographic problems. Between 1959 and 1979 population growth in Uzbekistan (and in Central Asia in general) far outstripped the rest of the USSR. In that period, Uzbekistan's population grew from 8,119,000 to $15,389,000$, an increase of $90 \%$, while by comparison the population of the Russian Republic grew from 117,534,00 to 137,410,000, or only $17 \% .^{71}$ As a percencage of the total population of the USSR, Russians fell from 56 percent to 52 percent while Uzbeks rose from 4 percent to 6 percent. In 1984 Lubin projected that by the year 2000 the Uzbek population might reach 30 million. ${ }^{72}$ Due to the rapidly growing population and the low level of industrialization, by 1979 Uzbekistan had a labour surplus that left overmanning in Uzbek industry as high as 18 percent. ${ }^{73}$ By comparison, much of the USSR faced relatively low population growth, an aging population, and in many key industrial areas, drastic labour shortages. ${ }^{74}$

Two solutions to this problem presented themselves. The first was to bring new industry to Uzbekistan. The attraction of new industries presenced several difficulties. To begin with, the faltering Soviet economy simply did not have the strength to make the necessary massive capital investment necessary for such a solution. Furthermore, such a shift in the Soviet economy would mean the "splitting of the centre of gravity of the Soviet politico-economic base with Soviet Moslems gaining in strength and power at Russia's expense. "75 Such a solution was hardly likely to appeal to Moscow. The second solution was to encourage out-migration from Uzbekistan. The Soviet champion of this solution, V. I. Perevedentsev, first voiced his concerns in 1966 when he protested that "a stupendous lack of utilization of the potential of the land occurs because of the inadequacy of the labour force," and suggested that

in the course of creating the basis for communism in material and equipment, the distribution of the population will have to change in accordance with the needs of raising the productivity of labour expended for society. ${ }^{76}$ 
In 1970 Perevedentsev proposed "an organised regulation of migration," and over the course of the 1970s he and other Soviet demographers debated how such a migration could be brought about. ${ }^{77}$ The most painless possibility was to permit Slavs living in Uzbekistan to migrate back to the European republics where they would provide much needed labour. ${ }^{78}$ This migration scheme would have required that Uzbeks move from rural to urban locations to fill the positions left vacant by the Slavs, however, and Uzbeks had shown a marked reluctance to accept such a move. ${ }^{79} \mathrm{Also}$, Moscow's control in Uzbekistan would have been diminished as locals filled administrative positions. The other possibility was to force migration. It is doubtful whether the Soviet Union was prepared to accept the international outrage that such a forced migration would surely have generated. Milder means such as reducing investment in the Uzbek economy and thereby intentionally worsening living condirions and making out-migration more desirable, were considered. ${ }^{80}$ Clearly the status quo was no longer acceptable to Moscow, and the need for changes in the relationship between Moscowand Uzbekistan was a pressing concern by the 1970 s.

If, as Rywkin and others suggest, a "gentlemen's agreement" existed between Uzbekistan and Moscow in the 1970s, the basis for that agreement had badly eroded long before Andropov came to power in November 1982. What is less apparent is that Moscow began to lay the groundwork for a new relationship with Uzbekistan in the 1970s. Although the move to replace Uzbeks with Slavs in important positions in the 1980 s has received justifiable attention, to infer that the designated Uzbek positions had existed for time immemorial would be incorrect. While by the 1980 s the position of Second Secretary in the Central Asian republics was generally regarded as a "watch-dog" position to be held by a Slav, before 1971 every second secretary in Central Asia was a titular Central Asian. ${ }^{81}$ These positions were gradually filled by Slavs between 1971 and $1976 .{ }^{82}$ These moves, which accompanied the debate over the need to induce migration from Central Asia, cannot be linked solely or even directly to that debate, but they do suggest an increased concern in the Kremlin regarding its channels of authority in Central Asia.

Between 1977 and 1981 there was also a rash of demotions and firings in the upper levels of the Uzbek government. The First Secretaries of the Bukharin, Samarkand, and Fergana Obkoms, the chairman of the Presidium of the Uzbek Supreme Soviet, the Minister of Internal Affairs, the Minister of Forestry, and the First 
Secretary of the Board of the Writer's Union all lost their positions. ${ }^{83}$ Although some of these changes may have been linked to the dispute between Rashidov, Kurbanov, and Nasreddinova discussed above, the possibility that Moscow initiated the changes cannot be dismissed.

Besides such direct political action, Moscow also launched a major campaign to encourage the use of the Russian language in Uzbekistan in 1978. Language is implicitly linked with nationalism, and Moscow was well aware that "if one is dominant in language, then likely one is dominant politically and economically. ${ }^{84}$ While the attempt to increase the use of the Russian language in Uzbekistan had been going on since Imperial Russia invaded Central Asia in the nineteenth century, the program begun in October 1978 with the decree of the USSR Council of Ministers "On Measures For Further Improving the Study and Teaching of the Russian Language in the Union Republics" was exceptional for the sheer size of the cadres brought in from the European republics. ${ }^{85}$

Moscow also sharply redefined its policy roward the Islamic faith in the late 1970s and early 1980s. This policy had always been a contradictory one, for while the Kremlin wished to discourage the practice of religion within the USSR, the status of Soviet Islamic leaders in the international Islamic community provided the USSR with a unique opportunity to influence affairs in the Muslim world. ${ }^{86}$ In the 1960s and 1970s, Soviet Islamic leaders were allowed to stage several conferences in Tashkent that attracted attention from the entire Islamic world. They planned a major conference for September 1980 to celebrate the fifteenth century of the Hejira, but the Soviet invasion of Afghanistan severely damaged the reputation of the Sovier Muftis, and only seventy-six of over five hundred invitees to the conference attended. ${ }^{87}$ Over the following two years Brezhnev replaced three of the four Soviet Muftis with much younger men, who have since come to be acknowledged as obvious agents of Soviet, as opposed to Islamic, ideology. ${ }^{88}$

Along with the language campaign and the replacement of Uzbek officials with Slavs, the religious purges were a clear example of Brezhnev's move to reinforce his authority in the republic. These actions revealed increased concern in Moscow over events in Uzbekistan, and Brezhnev made his concerns explicit at the twentysixth Party Congress in 1981 when he reintroduced the idea of the "merging of nations," a policy last touted by Khrushchev. ${ }^{89}$ In 
September of that year he also introduced harsh new legislation to deal with economic crime. ${ }^{90}$ Between September 1981 and his death in November 1982, Brezhnev made frequent references to the fact that there were too many locals in republican party organizations. ${ }^{91}$ When he spoke in Tashkent on 24 March 1982, he criticised Uzbekistan's preoccupation with its own cultural heritage and questioned the "real or perceived movement toward a predominance of Uzbeks in official positions." "92 Meanwhile, on 4 December 1981 in the Uzbekiscan newspapers Pravda Vostoka and Sovet Ozbekistan, an article under the signature of Usmankhodzhaev, then the chairman of the Presidium of the Uzbek Supreme Soviet, gave an "unusually exhaustive portrayal of economic crime in Uzbekistan. ${ }^{\text {"93 }}$ At the time this article was published, Bess Brown from Radio Liberty interpreted it as an indication that "Uzbekistan is actively joining in the Union-wide campaign against corruption that is reported to have been launched." 94

Clearly a movement to attack corruption, or perhaps to attack the Uzbek elite under the guise of an attack on corruption, was underway in Uzbekistan before Brezhnev's death. In order to interpret this new stance as a policy initiated by Andropov, it is necessary to assume that Andropov had sufficient power by the twenty-sixth Party Congress in 1981 to play a significant role in the determination of policy. Andropov undoubtedly supported the policy, as he demonstrated in an April 1982 speech:

The justified indignation of the Soviet people is aroused by cases of theft, bribery, bureaucratism, a disrespectful attitude to people, and other social phenomena... As long as such phenomena exist, they hinder us. ${ }^{95}$

There is no evidence, however, to suggest that Andropov played any significant role in the setting of nationalities policy before his promotion to the Central Committee Secretariat in May 1982. ${ }^{96}$ Furchermore, there is sound evidence to suggest that the use of corruption purges to reassert Moscow's authority in the republics was a part of Brezhnev's standard operating procedure.

The principal examples of this policy occurred in 1969 in Azerbaijan and in 1972 in Georgia, where Brezhnev purged the local Communist Parties. In both cases, problems of ethnic unrest preceded the purges. In Azerbaijan, demonstrations and growing Islamic activities prompted the appointment of Geidar A. Aliev, 
previously chairman of the Azerbaijan KGB, as Party First Secretary. ${ }^{97}$ Over the following seven years, fifteen Raikom first secretaries and twenty-five percent of the heads of local Soviets were sacked. ${ }^{98}$ In Georgia, in the wake of a scandal surrounding the publication of V. I. Didamonidze's $A$ Historiography of the Bourgeois-Democratic Movement and the Victory of the Socialist Revolution in Georgia (19171921), a highly nationalistic and "revisionist" volume, Eduard Shevardnadze, the head of the republican MVD, was promoted to First Secretary of the Georgian Communist Party. ${ }^{99}$ The purges instituted by Shevardnadze continued for ten years and brought wholesale changes at every level of the Georgian administration. ${ }^{100}$

To claim that the events in Uzbekistan represented a radical departure by Andropov would be to ignore the chain of events in Uzbekistan leading up to the purges, a chain of events that occurred under Brezhnev's rule, and the antecedents to the Uzbek purges in the Georgian and Azerbaijanian episodes. In Azerbaijan and Georgia, as in Uzbekistan, after a period of ethnic unrest the government initiated large-scale purges of the upper echelons of the Party in order to bring the republic back under the firm control of Moscow. The primary difference is that in Georgia and Azerbaijan, Slavs were not brought in to fill positions traditionally held by locals. The continuity, however, between Brezhnev's policy and the policies of Andropov and Gorbachev is far more significant. 


\section{NOTES}

'Anne Sheehy, "Uzbek Central Committee Plenum Reveals Widespread Corruption," Radio Liberty Research Bulletin 254 (28 June 1984)

${ }^{2}$ Due to limitations of space, this essay is restricted to discussing events in Uzbekistan. Soviet policies towards Uzbekistan, however, are only a component part of their policies towards Soviet Central Asia in general.

${ }^{3}$ Nancy Lubin, Labour and Nationality in Soviet Central Asia: An Uneasy Compromise (London, 1984), 196

${ }^{4}$ Konstantin M. Simis, USSR: The Corrupt Society. The Secret World of Soviet Capitalism trans. Jacqueline Edwards \& Mitchell Schneider (New York, 1982), 47

'Michael Rywkin, Moscow's Muslim Challenge: Soviet Central Asia (New York, 1990), 150

"Boris Z. Rumer, Soviet Central Asia: "A Tragic Experiment," (Boston, 1989), 147

7 Simis, The Corrupt Society, 60

${ }^{8}$ Ibid., 63

${ }^{9}$ Lubin, Labour and Nationality, 174

${ }^{10}$ Rumer, Soviet Central Asia, 62

"United States, USDA Foreign Agriculture Service, "U.S. Team

Reports on Soviet Cotton Production and Trade," June, 1977)

${ }_{12}$ Rumer, Soviet Central Asia, 62-64

${ }^{13}$ Leslie Dienes, Soviet Asia: Economic Development and National Policy Choices (Boulder, Co., 1987), 123

${ }^{14}$ Dienes, Soviet Asia, 124-125

is Lubin, Labour and Nationality, 181

${ }^{16}$ Ibid., 193

17 Ibid., 169

18 James Critchlow, "Corruption', Nationalism, and the Native Elites in Central Asia," The Journal of Communist Studies 4 (June, 1988), 144

19 Jonathan Steele \& Eric Abraham, Andropov in Power: From Komsomol to Kremlin (Oxford, 1983), 149-151

${ }^{20}$ Steele \& Abraham, Andropov in Power, 145

${ }^{21}$ Anne Sheehy, "New Agricultural Secretary in Uzbekistan," Radio Liberty Research Bulletin 430 (7 September 1988)

22 Ibid. 
${ }^{23}$ Bess Brown, "The Progress of Restructuring in Uzbekistan," Radio Liberty Research Bulletin 246 (25 June 1987)

${ }^{24}$ Sheehy, "New Agricultural Secretary in Uzbekistan"

2s Soviet Analyst 7 (29 June 1978)

${ }^{26}$ Anne Sheehy, "Major Anti-Corruption Drive in Uzbekistan," Radio Liberty Research Bulletin 324 (30 August, 1984); Critchlow, "Corruption, Nationalism, and the Native Elites," 146

27 Bess Brown, "Party Personnel Changes in Uzbekistan," Radio Liberty Research Bulletin,52 (2 February, 1984)

${ }^{28}$ Respectively, Tukhtamysh Baimirov, Ruzmet Gaipov, and Kallibek Kamalov. Sheehy, "Major Anti-Corruption Drive in Uzbekistan" ${ }^{29}$ Respectively, Vali Muratkhodzhaev, D. Shapirov, and Vakhobzhan Usmanov. Sheehy, "Major Anti-Corruption Drive in Uzbekistan" ${ }^{30}$ Respectively, Ubaidulla Turakulov, Makhkam Kamalov, and Abduvakhid Karimov. Anne Sheehy, "Progress of Anti-Corruption Campaign in Uzbekistan Reviewed," Radio Liberty Research Bulletin 457 (29 November 1984)

${ }^{31}$ Sheehy, "Progress of Anti-Corruption Campaign in Uzbekistan Reviewed"

32 Ibid.

33 Ibid.

34 Ibid.

${ }^{35}$ Respectively Ziyat Esenbaev, Sarvar Alimdzhanovich Azimov, and Abid Sadykovich Sadykov. Anne Sheehy, "Dismissed Uzbek Officials Fight Back," Radio Liberty Research Bulletin 403 (4 December 1985)

${ }^{36}$ Among the most prominent were: Salim Pulatov, Minister of Higher and Specialized Secondary Education (August 1985); Academician Ukcam Aripov, rector of the Tashkent Medical Institute (November 1985); Saidkarim Kadyrkhanov, Professor of Economics at the Tashkent Economics Institute and Deputy Secretary of the Institute's Party Committee (January 1986); Anvar Agzamkhodzhaev, Dean of the Law Faculty at Tashkent State University and corresponding member of the Uzbek SSR Academy of Sciences (January 1986); A. Shamaksudov, Dean of the Department of Journalism at Tashkent State University (January 1986); and Nikolai Timofeev, Editor in Chief of the main Russian-language Party newspaper in Uzbekistan, Pravda Vostoka (January 1986). For Putalov, Aripov, Kadyrkhanov, Agzamkhodzhaev \& Shamaksudov, see Joseph Seagram, "Corruption in Uzbek Higher Education," Radio Liberty 
Research Bulletin 90 (13 February 1986). For Timofeev, see Seagram, "Problems in Publishing Spotlighted at Party Congresses in Central Asia," Radio Liberty Research Bulletin 123 (7 March 1986)

${ }^{37}$ Anne Sheehy, "Slav Presence Increased in Uzbek Parry Buro and Secretariat," Radio Liberty Research Bulletin 94 (24 February 1986) ${ }^{38}$ Ibid.

${ }^{39}$ Ibid.

${ }^{40}$ Ibid.

${ }^{41}$ Bess Brown, "New Party First Secretary In Uzbekistan," Radio Liberty Research Bulletin 20 (12 January 1988)

42 Ibid.

${ }^{43}$ The most prominent positions and the Slavs that filled them were: Chief Public Procurator - Aleksei Buturlin; Chief of the Administrative Organs of the Uzbek Party Central Committee - V. G. Kretov; Secretary of the Uzbek Communist Party - Victor Nikolaevich Lobko; Firstsecretary of the Tashkent Party Committee - B. F. Satin; Two positions on the Uzbek Supreme Court Aleksandr Ivanovich Lipatov and Svetlena Nikolaevna Mel'chenko; Chairman of the People's Control Committee - Viktor A. Khaidurov; Secretary of the Uzbek Party Central Committee responsible for Industry - Vadim Petrovich Anishchov; Second Secretary of the Khorezm Obkom - Yurii P. Gudkov; Second Secretary of the Andizhem Obkom - Viktor A. Smeyushchev. (See Radio Liberty Research Bulletin 324 (30 August 1984); Radio Liberty Research Bulletin 94 (24 February 1986); Radio Liberty Research Bulletin 333 (3 October 1985); Radio Liberty Research Bulletin 254 (28 June 1984)

${ }^{44}$ Anne Sheehy, "Slav Presence Increased in Uzbek Party Buro and Secrecariat," Radio Liberty Research Bulletin 94 (24 February 1986) ${ }^{45}$ Ibid.

${ }^{46}$ Michael Rywkin, "Perestroika in Central Asia," The Nationalities Papers 17:1 (Spring 1989), 51; Rywkin, Moscow's Muslim Challenge, 151

${ }^{47}$ Rywkin, Moscow's Muslim Challenge, 154

${ }^{48}$ Ibid.

${ }^{49}$ Rumer, Soviet Central Asia, 158

so Anne Sheehy, "Problems in the Cotton Fields of Uzbekistan," Radio Liberty Research Bulletin 149 (9 May 1985)

"1 Brown, "Rashidov on Boosting Cotton Production in Uzbekistan," Radio Liberty Research Bulletin 400 (7 October 1981) 
52 "U.S. Team Reports on Soviet Cotton Production and Trade" "S3 Sheehy, "Problems in the Cotton Fields of Uzbekistan"

${ }^{54}$ Dienes, Soviet Asia, 143

ss "U.S. Team Reports on Soviet Cotron Production"

${ }^{56}$ Quoted in Rumer, Soviet Central Asia, 71

57 Brown, "Rashidov on Boosting Cotton Production in Uzbekistan"

${ }^{58}$ Bess Brown, "Brezhnev Mixes Praise and Criticism of Uzbekistan in Tashkent Speech," Radio Liberty Research Bulletin 140 (25 March 1982); Anne Sheehy, "Uzbek Cotton Harvest Falls Short of Target," Radio Liberty Research Bulletin 414 (12 December 1985)

"9 Rumer, Soviet Central Asia, 70

${ }^{60}$ Ibid., 71

${ }^{61}$ Lubin, Labour and Nationality, 241

${ }^{62}$ Ibid., 241-242

${ }^{63}$ Jan-Ake Dellenbrant, "The Central Asian Challenge: Soviet Decision-Making on Regional Stability under Brezhnev and Gorbachev," The Journal of Communist Studies 4 (March 1988), 65 ${ }^{64}$ John Soper, "Uzbek Writers Look To The Past For Inspiration," Radio Liberty Research Bulletin 129 (24 April 1979)

"s Anne Sheehy, "Uzbek Novel Found Ideologically Unsound," Radio Liberty Research Bulletin 337 (20 August 1982); Anne Sheehy, "Nationalistic Tendencies in Recent Uzbek Historiography and Historiographical Fiction Under Attack," Radio Liberty Research Bulletin 11 (23 December 1986)

${ }^{66}$ Murray Feshbach and Alfred Friendly, Jr., Ecocide in the USSR: Health and Nature Under Seige (New York, 1992), 74

${ }^{67}$ Rumer, Soviet Central Asia, 81-83

${ }^{68}$ Dienes, Soviet Asia, 124

${ }^{69}$ Lubin, Labour and Nationality, 234

${ }^{70}$ Quoted in Feshbach and Friendly, Ecocide in the USSR, 75

1 Viktor Kozlov, The Peoples of the Soviet Union, trans. Pauline M.

Tiffen (London, 1988), 79-83

${ }^{72}$ Lubin, Labour and Nationality, 49

${ }^{73}$ Ibid., 70

${ }^{74}$ Rywkin, Moscow's Muslim Challenge, 67-71

${ }^{75}$ Michael Rywkin "The Political Implications of Demographic and Industrial Developments in Soviet Central Asia," The Nationalities Papers 7 (Spring 1979), 26

${ }^{76}$ V. I. Perevedentsev, Population Movement and Labour Supply in Siberia in 2 parts in The Soviet Review 10:1 (Spring 1969) and 10 
(Summer 1969), 10, 31

${ }^{77}$ Rywkin, "The Political Implications of Demographic and Industrial Developments," 30-31

${ }^{78}$ Rywkin, "The Political Implications of Demographic and Industrial Developments," 39-42

${ }^{79}$ Lubin, Labour and Nationality, 153

${ }^{80}$ Rywkin, Moscow's Muslim Challenge, 75

${ }^{81}$ Christian Dueval, "Changing Patterns in the Top 'Watchdog' Appointments to the Union Republics," Radio Liberty Research Bulletin 365 (28 July 1976)

${ }^{82}$ Dueval, "Changing Patterns in the Top 'Watchdog' Appointments to the Union Republics"

${ }^{83}$ Respectively, K. Murtazaev (Feb. 1977); B. R. Rakhimov (Feb. 1982); F. Sh. Shamsudinov (Dec. 1978); N. M. Matchanov (Dec. 1978); Kh. Kh. Yakh'yaev (? 1979); S. M. Tairov (Dec. 1979); Kamil Yashen (Nov. 1980). (See Radio Liberty Research Bulletin 52 [2 February 1984]; Radio Liberty Research Bulletin 40 [25 January 1980]; Radio Liberty Research Bulletin 445 [24 November 1980]; Radio Liberty Research Bulletin 122 [16 March 1982])

${ }^{84}$ Allan Kagedan, "Nationalism, Language, and Culture," The Nationalities Papers 14 (1991), 59

${ }^{85}$ Roman Solchanyk, "Russification to be Stepped Up," Soviet Analyst 9 (9 January 1980)

${ }^{86}$ Alexandre Bennigsen et ah Soviet Strategy and Islam (London, 1989), 38

${ }^{87}$ Bennigsen, Soviet Strategy and Islam, 58-59

${ }^{88}$ Ibid., 59-61

${ }^{89}$ Anne Sheehy, "Andropov and the Merger of Nations," Radio Liberty Research Bulletin 516 (22 December 1982)

${ }^{90}$ Elizabeth Teague, “Andropov's First Hundred Days: Domestic Policy," Radio Liberty Research Bulletin 92 (21 February 1983)

${ }^{91}$ Bess Brown, "The National Composition of the Governments of the Central Asian Republics," Radio Liberty Research Bulletin 313 (4 August 1982)

92 Brown, "Brezhnev Mixes Praise and Criticism of Uzbekistan in Tashkent Speech," Radio Liberty Research Bulletin 140 (25 March 1982)

${ }_{93}$ Bess Brown, "Revelations of Economic Crime in Uzbekistan," Radio Liberty Research Bulletin 503 (16 December 1981) ${ }^{94}$ Ibid. 
95 Elizabeth Teague, "Room at the Top," Radio Liberty Research Bulletin 460 (18 November 1982)

${ }^{95}$ Steele \& Abraham, Andropov in Power, 144

${ }^{97}$ Elizabeth Fuller, "Aliev Gains Full Membership in the Politburo and a First Deputy Premiership," Radio Liberty Research Bulletin 471 (24 November 1982)

${ }_{98}$ Elizabeth Fuller, "Corruption and Retribution in Azerbaijan," Radio Liberty Research Bulletin 413 (14 October 1982)

${ }^{99}$ Christian Dueval, "Nationalist Rumblings in Georgia," Radio Liberty Dispatch. (10 May 1972); Fuller, "Georgian Procuracy Personnel Depleted by Ongoing Anti-Corruption Campaign," Radio Liberty Research Bulletin 284 (1 August 1980)

100 See Elizabeth Fuller, "Shevardnadze Reviews Progress on the Economic and Ideological Front," Radio Liberty Research Bulletin 262 (24 July 1980); Fuller, "Georgian Procuracy Personnel Depleted by Ongoing Anti-Corruption Campaign"; Elizabeth C. Scheetz, "Criticism of the Administrative Organs in Georgia," Radio Liberty Research Bulletin 60 (14 March 1977) 